\title{
The first long-term survival results of lung transplantation in Turkey
}

\author{
Türkiye'de akciğer nakli sonrası ilk uzun dönem sağkalım sonuçları

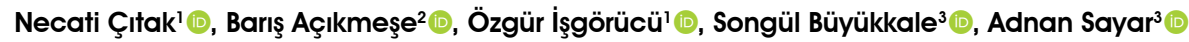 \\ Institution where the research was done: \\ Bakırköy Dr. Sadi Konuk Training and Research Hospital, Istanbul, Turkey \\ Author Affiliations: \\ Department of Thoracic Surgery, Bakirköy Dr. Sadi Konuk Training and Research Hospital, Istanbul, Turkey \\ Department of Chest Diseases, Bakırköy Dr. Sadi Konuk Training and Research Hospital, Istanbul, Turkey \\ Department of Thoracic Surgery, Private Memorial Hospitals Group, Istanbul, Turkey
}

Lung transplantation (LTx) has become mainstay of therapy for end-stage lung diseases all over the world.$^{[1]}$ According to the International Society for Heart and Lung Transplantation (ISHLT) database, 67,072 adult lung and heart-lung transplants performed until 2017

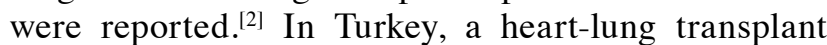
was performed for the first time in a nine-year-old girl with large vessel transposition and restrictive ventricular septal defect who developed pulmonary hypertension in 1998 at the Dokuz Eylül University, School of Medicine. ${ }^{[3]}$ The early period LTx results of our LTx center were published by us four years ago. ${ }^{[4]}$ It was the first study to publish the results of patients in our country. In this study, we retrospectively analyzed 31 LTx cases (21 bilateral, eight single-sided, and two re-transplantations) performed in 29 patients (17 males, 12 females; mean age: $41.4 \pm 11.7$ years; range, 19 to 59 years) at Yedikule Chest Diseases and Thoracic Surgery Training and Research Hospital between March 2012 and February 2015. After the early period results, we present our long-term results of patients who underwent LTx.

Of the patients, $12(38.7 \%)$ are alive who have been under follow-up since a mean of $49.5 \pm 7.8$ months (range, 0 to 100 months). After the first published study, six patients died during follow-up. Two patients
(Patient 10 and Patient 26) died of bronchiolitis obliterans syndrome at post-transplant $38^{\text {th }}$ and $51^{\text {st }}$ months. Two patients (Patient 20 and Patient 22) died of graft failure at post-transplant $24^{\text {th }}$ and $26^{\text {th }}$ months. One patient (Patient 1) died of an inoperable lung cancer that was in the transplanted lung at post-transplant $61^{\text {st }}$ month. The remaining one patient (Patient 4) died of pneumonia that was in the native lung at post-transplant $80^{\text {th }}$ month.

Survival for all patients (including surgical mortality) at one, three, and five years were $61.3 \%$, $51.6 \%$, and $41.9 \%$, respectively (median: 39 months). However, when one-year post-transplant conditional survival analysis was performed, there were significant subsequent differences at any age group. Therefore, the ISHLT recommend that it would be more accurate to apply a survival analysis in patients who met the one-year survival condition. ${ }^{[2]}$ According to this recommendation, we observed that the survival rates at three and five years were $84.2 \%$ and $68.4 \%$, respectively (median: 79 months). These rates were comparable with the results of the latest ISHLT database (Figure 1).

To the best of our knowledge, the current study is the first study to present the long-term survival in patients

Received: July 10,2020 Accepted: September 07, 2020 Published online: October 20, 2021

Correspondence: Necati Çıtak, MD. Bakırköy Dr. Sadi Konuk Eğitim ve Araştırma Hastanesi, Göğüs Cerrahisi Kliniği, 34147 Bakırköy, İstanbul, Türkiye. Tel: +90 212 - 4147256 e-mail: necomomus@gmail.com 


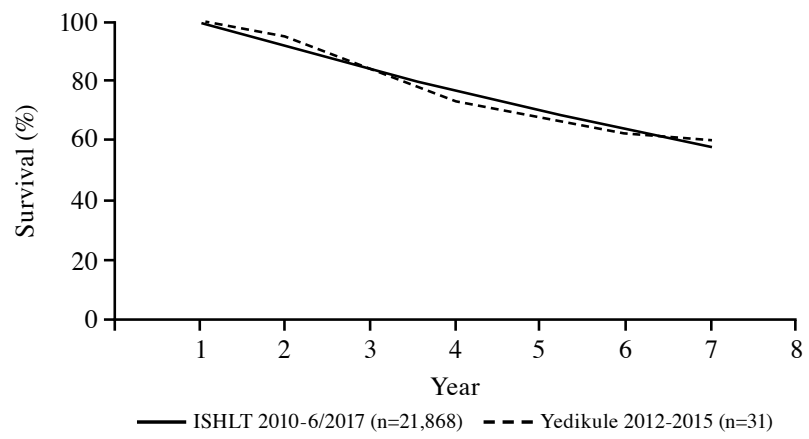

Figure 1. Kaplan-Meier survival analysis showing lung transplants conditional on survival to one year and comparison of the results with the ISHLT database.

ISHLT: International Society for Heart and Lung Transplantation.

who underwent LTx in Turkey. In accordance with the ISHLT published database on LTx, our survival results for the transplant patients were comparable. Lung transplantation provides significant survival rates in selected patients and LTx centers in our country should be supported and encouraged in all aspects.

\section{Declaration of conflicting interests}

The authors declared no conflicts of interest with respect to the authorship and/or publication of this article.

\section{Funding}

The authors received no financial support for the research and/or authorship of this article.

\section{REFERENCES}

1. Büyükkale S, Bakan ND, Çıtak N, İşgörücü Ö, Sayar A. Akciğer naklinde güncel durum değerlendirmesi. Turk Gogus Kalp Dama 2016;24:398-407.

2. Overall Lung and Adult Lung Transplantation Statistics. The International Society for Heart and Lung Transplantation Registry Data Slides. Available at: https://ishltregistries.org/ registries/slides.asp [Accessed: July 06, 2020]

3. Oto Ö, Açıkel Ü, Hazan E, Çatalyürek H, Sarıosmanoğlu N, Silistreli E, et al. Çocukluk çağında kalp ve akciğer transplantasyonu: Ülkemizde ilk uygulama. Turk Kardiyol Dern Ars 1998;26:446-8.

4. Büyükkale S, Çıtak N, İşgörücü Ö, Kalafat CE, Aksoy Y, Cemaller Ç, et al. Yedikule organ nakli merkezinin erken dönem akciğer nakli sonuçları: Üç yıllık deneyimimiz. Turk Gogus Kalp Dama 2017;25:86-95. 